$\frac{8}{12} / 191 \quad \omega B \quad 2$

\title{
CNC Grinding of Valve Housing Piston Holes
}

F. A. Ashbaugh

KCP-613-4474

Published November 1991

Final Report

Prepared for the United States Department of Energy Under Contract Number DE-ACO4-76-DP00613. 


\section{DISCLAIMER}

This report was prepared as an account of work sponsored by an agency of the United States Government. Neither the United States Government nor any agency thereof, nor any of their employees, makes any warranty, express or implied, or assumes any legal liability or responsibility for the accuracy, completeness, or usefulness of any information, apparatus, product, or process disclosed, or represents that its use would not infringe privately owned rights. Reference herein to any specific commercial product, process, or service by trade name, trademark, manufacturer, or otherwise, does not necessarily constitute or imply its endorsement, recommendation, or favoring by the United States Government or any agency thereof. The views and opinions of authors expressed herein do not necessarily state or reflect those of the United States Government or any agency thereof.

Printed in the United States of America.

This report has been reproduced from the best available copy.

Available to DOE and DOE contractors from the Office of Scientific and Technical Information,

P. O. Box 62, Oak Ridge, Tennessee 37831; prices available from (615) 576-8401, FTS 626-8401.

Available to the public from the National Technical Information Service, U. S. Department of Commerce, 5285 Port Royal Rd., Springfield, Virginia 22161.

A prime contractor with the United States Department of Energy under Contract Number DE-ACO4-76-DP00613.
Kansas City Division P.O. Box 419159

Kansas City, Missouri 64141-6159 
$\mathrm{KCP}-613-4474$

Distribution Category UC-706

$\mathrm{KCP}--613-4474$

DE92 002663

CNC GRINDING OF VALVE

HOUSING PISTON HOLES

F. A. Ashbaugh

Published November 1991

Final Report

F. A. Ashbaugh, Project Leader

Technical Communications

Kansas City Division 
CNC GRINDING OF VALVE HOUSING PISTON HOLES

KCP-613-4474, Final Report, Published November 1991

Prepared by F. A. Ashbaugh

Grinding has traditionally been used for machining operations requiring close dimensional tolerances and good surface finishes. With the development of new CNC grinders, tools, and machining techniques, it is now practical to machine critical features such as are found on valve housing piston holes. 


\section{CONTENTS}

Section

Page

SUMMARY

DISCUSSION. • . • . . . . . . . . . . . . . . 9

SCOPE AND PURPOSE . . . . . . . . . . . . . . . . . . 9

PRIOR WORK. . . . . . . . . . . . . . . . . 9

ACTIVITY. • . . . . . . . . . . . . . . . . . 9

ACCOMPLISHMENTS • . . . . . . . . . . . . . 12

FUTURE WORK . . . . . . . . . . . . . . . . 12

\section{ILLUSTRATION}

Figure

Page

1

Solid Carbide Grinding Tool. . . . . . . . .

10 


\section{SUMMARY}

The critical inside features of the piston holes on valve housings present a variety of manufacturing problems that account for numerous rejects, rework, scrapped parts, and deviations. Some of these problems involve surface finish, close tolerances, heavy burrs (especially at the cross holes), nicks, scratches, small inside radii, waviness, chatter, bellmouth, and workmanship.

Heavy burrs at the cross holes contribute to many of these defects. In removing the burrs at the cross holes, the inside surfaces are damaged (nicks and scratches), which requires additional rework and polishing. Polishing has been a necessary traveler operation to obtain the required surface finish and to remove any marks from deburring, rework, or gaging.

Grinding has traditionally been used for machining operations requiring close dimensional tolerances and better surface finishes than can be obtained from other metal removal techniques. Using a grinding process for the last metal removal operation, the close tolerances and surface finishes can be easily held while eliminating the adverse conditions from the current metal removal processes.

Pre-machined test parts were sent to a machine tool supplier to have the critical inside features of a typical piston bore finish machined using an internal CNC grinder equipped with high-frequency spindles. The piston bore and sealing angle were ground using a standard 120-grit silicon carbide wheel. The wafer step was machined using a solid carbide tool designed and built at Allied-Signal Inc., Kansas City Division (KCD).

Six consecutive parts were machined for evaluation. The repeatability on all six parts was within print requirements. The inside corner radii was less than $0.002 \mathrm{in}$. and the surface finish was 8.2 arithmetical average or better as defined by ANSI B46.1, Surface Texture.

Machining parts by this grinding process would eliminate bellmouth, chatter, waviness, and traveler polishing operations. It would produce a superior surface finish, small inside radii, and small easily removable burrs. It would also hold tolerances closer and significantly reduce scrap, rework, rejects, and deviations. 


\section{DISCUSSION}

\section{SCOPE AND PURPOSE}

The purpose of this project was to evaluate the capability of producing the critical inside surfaces of valve housing piston holes using CNC inside diameter (ID) grinders. Grinding of these features is expected to reduce deburring time, polishing, rework, scrap, and deviations. Superior, uniform sealing angle surfaces and a more consistent process are also expected.

\section{PRIOR WORK}

Grinding has traditionally been the preferred machining method when close tolerances and good surface finishes are required. However, at KCD, piston holes have normally been produced using form reamers. This process does not produce consistent surface finishes. It has the potential to cause bellmouthing, and it always creates heavy burrs at the cross holes. ID grinding has never been employed in the valve manufacturing process at KCD.

\section{ACTIVITY}

For this evaluation, CNC ID grinders equipped with highfrequency spindles were selected. The benefits expected were good uniform surface finish, little or no burrs at the cross holes, close tolerances, and very small inside radii. The grinding process would also eliminate polishing operations, nicks, scratches, waviness, chatter, and bellmouthing, while reducing scrap, rework, deviations, and rejects for workmanship.

Grinding of piston holes has been contemplated at KCD for several years. Recent developments in CNC grinders, highfrequency spindles, and tooling now make grinding of small holes, forms, and shapes very practical.

Quotes were obtained from several qualified tool manufacturers to grind the critical inside surfaces of a typical piston hole. Several test parts were sent to the low bidder to be machined. Although this bidder was the lowest for machining the test parts, they are one of the top three machine tool builders that offer a machine that can meet KCD requirements.

The test parts were machined on a CNC high precision internal grinding machine using a 120,000-rpm high-frequency spindle. The test parts were scrapped production parts that were finished 
to print requirements on the piston holes. These tests removed approximately 0.002 in. on all surfaces. This evaluation did not require that print dimensions be held. The primary concerns were repeatability of diameters, depths, and surface finish. In actual production, parts will be completely finished except approximately 0.002 in. of material will be left on all critical surfaces of the piston hole.

The CNC grinder will be the last metal removal operation. This operation will replace two current operations to finish size the piston bore, the sealing angle, and the wafer step. It will also eliminate the polishing operation now required on all valves. The piston bore and sealing angle surface were ground using a standard 120-grit silicon carbide wheel. The wafer step was machined using a special solid carbide tool designed and built at KCD (Figure 1). Experience at KCD has proven that a solid carbide tool running at very high speeds and taking very light cuts will show minimal wear after extended use. This tool is the key to holding a $0.002-i n$. maximum inside radius.
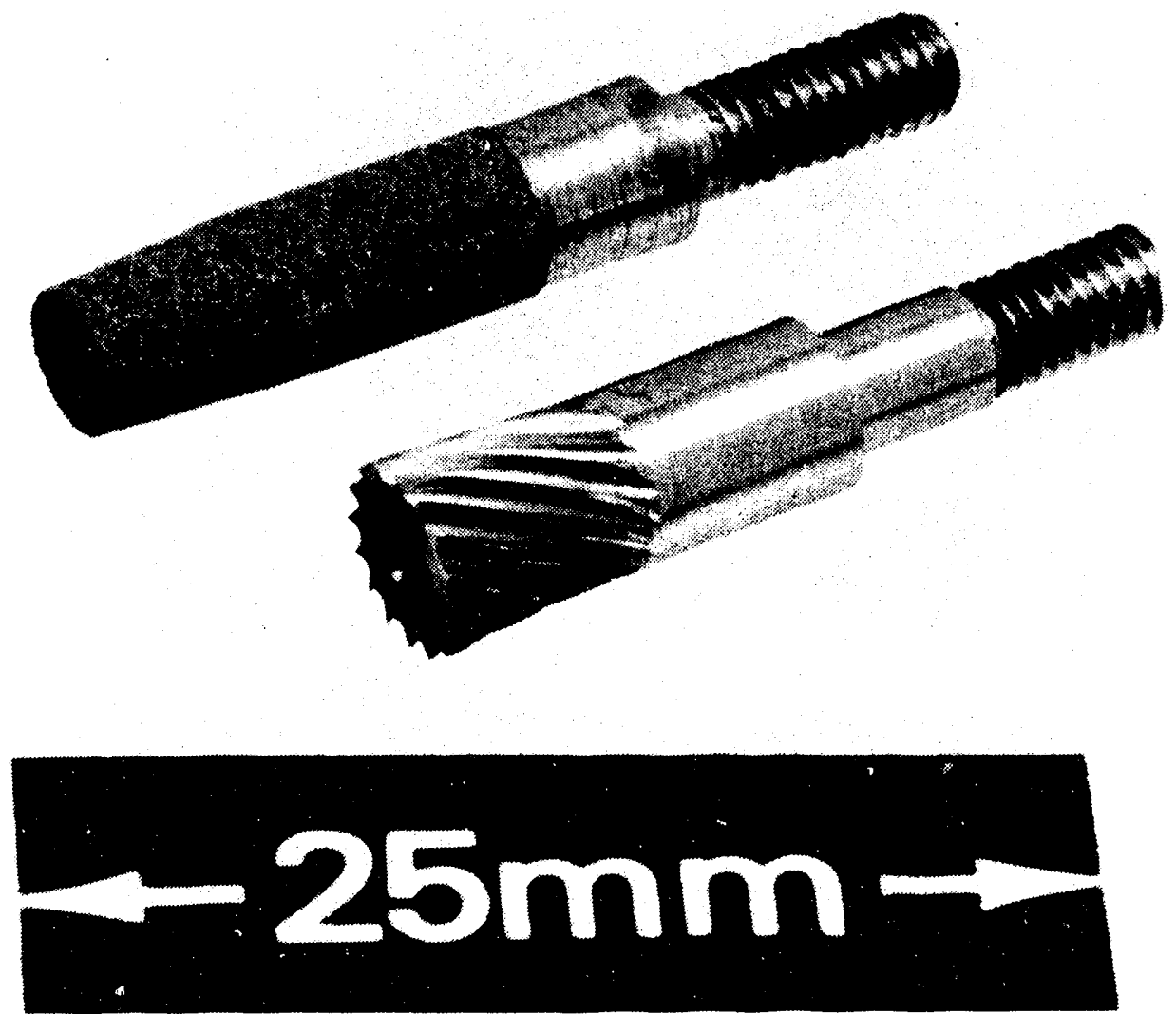

Figure 1. Solid Carbide Grinding Tool 
After initial setup, six consecutive test parts were machined to evaluate the machine for capability and repeatability. These parts were machined without changing tools or tool settings. The following 1 ist shows the print requirements and the test results.

\section{PRINT REQUIREMENTS}

1. A surface finish of 32 , free of nicks, scratches, and lay lines.

2. Diameters within \pm 0.0004 in.

3. Depth to shoulders within \pm 0.0004 in.

4. Depths to angles (over balls) within \pm 0.008 in.

5. Some bellmouthing allowable.

6. No physically detectable raised metal on the sealing angle surface.

7. 0.002-in. maximum radius.

\section{TEST RESULTS}

An 8.2 arithmetical average (worst cindition) with uniform surface texture.

$0.0005-i n \cdot$ total indicator reading ( $T I R$ ) total variation on all parts.

$0.0004-$ in. TIR total variation on all parts.

Maximum variation of 0.0028 in. checking over three sets of balls; $0.230-, 0.238-$, and $0.240-$ in. diameters.

Bellmouthing eliminated.

Burrs at the cross holes were virtually eliminated.

$0.001-$ in. radius.

All of the features are within the print requirements. It is expected that with proper machine adjustments (feeds, speeds, and programming) and tooling that some of these features could be improved.

Most of the variation in the diameters of the piston holes (ref. requirement 2) was caused by taper. Adjusting the head stock to eliminate the taper would result in a total diameter variation of 0.0002 in. 


\section{ACCOMPLI SHMENTS}

As anticipated, the CNC internal grinder can produce the critical features of valve housing piston holes. The surface finish and texture is much better than required. This is a natural result of the grinding process. The inside corner radius of the wafer step is less than 0.002 in. This is a result of the KCD in-house design of a solid carbide cutting tool. By using a solid carbide tool to finish the wafer step, the inside corner radius was held to 0.001 in. Using a CNC internal grinder as the last metal removal operation to finish the critical features of valve piston holes will eliminate heavy burrs, waviness, chatter, and bellmouthing. Nicks and scratches will be eliminated as a result of improved machining processes. Only marks from inspection and other secondary operations will appear. Flowtime, scrap, rework, and SXRs will be reduced.

\section{FUTURE WORK}

Production is planned for a quantity of development parts that can be tested and evaluated by the customer. 

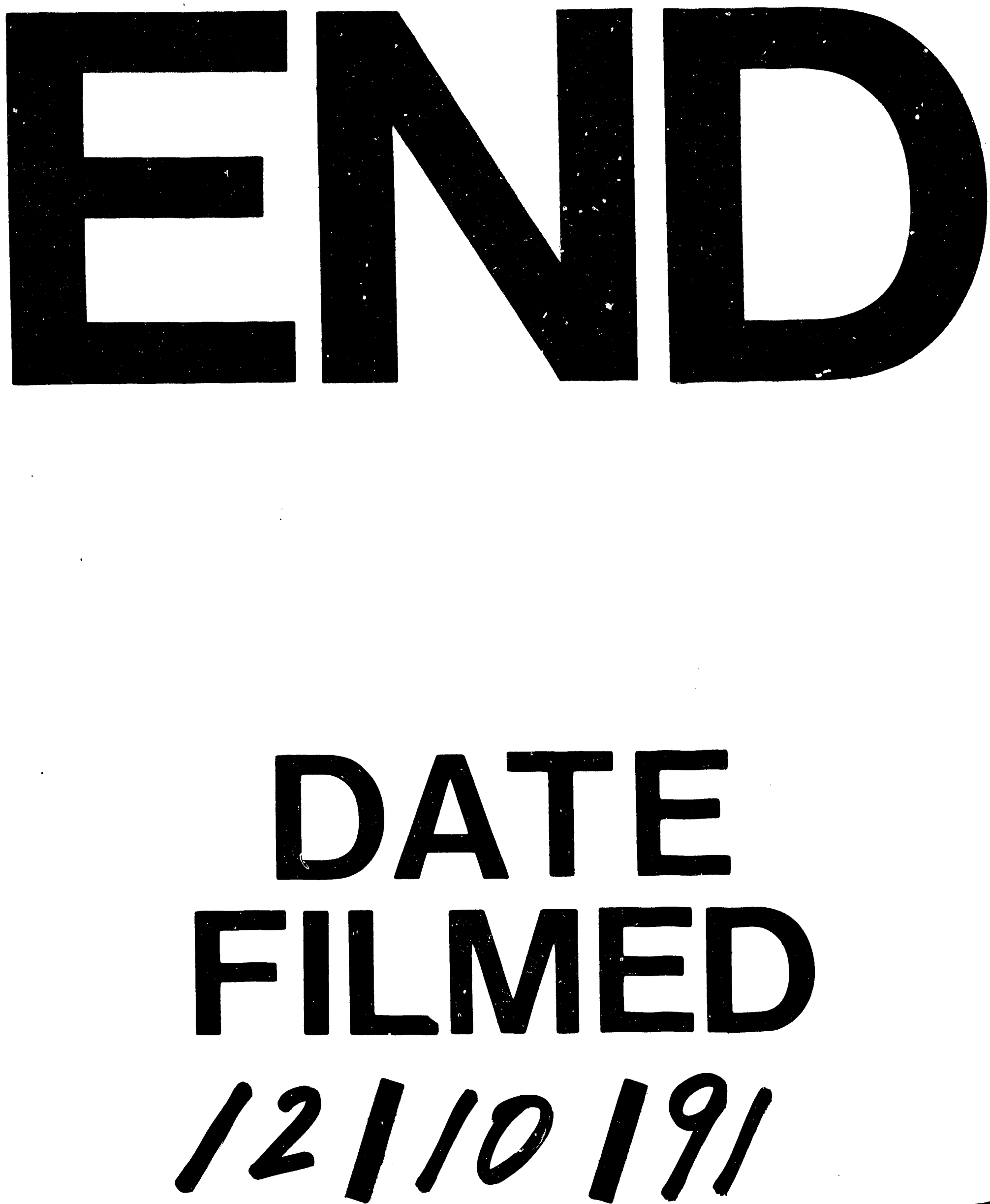

i 


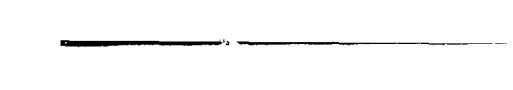

